\title{
IMPLIKASI HUKUM DIHAPUSKANNYA SURAT KETERANGAN TANAH DALAM SISTEM PENDAFTARAN TANAH PERTAMA KALI
}

\author{
Caesar Noor Ivan \\ Fakultas Hukum, Universitas Brawijaya \\ e-mail: caesarnoor@yahoo.com
}

\begin{abstract}
ABSTRAK
Surat Edaran Menteri Agraria dan Tata Ruang/BPN No. 1756/15.I/IV/2016 tentang Petunjuk Pelaksanaan Pendaftaran Tanah Masyarakat dibuat dengan alasan untuk mempermudah proses pendaftaran tanah tersebut. Surat Edaran tersebut menimbulkan permasalahan, yaitu kedudukan hukum dari Surat Edaran Menteri Agraria dan Tata Ruang/BPN No. 1756/15.I/IV/2016 tersebut di dalam Sistem Pendaftaran Tanah untuk pertama kali. Metode penelitian yang digunakan oleh penulis adalah metode penelitian normatif dengan menggunakan dua pendekatan yaitu pendekatan perundang-undangan serta pendekatan teoritik. Surat Edaran Menteri Agraria dan Tata Ruang/BPN No. 1756/15.I/IV/2016 tentang Petunjuk Pelaksanaan Pendaftaran Tanah Masyarakat dalam sistem pendaftaran bukan merupakan aturan perundang-undangan, disebabkan karena tidak terdapat dalam tata urutan UU No. 12 Tahun 2011, akan tetapi hanya mengikat ke dalam, selain itu keberadaannya juga menghilangkan alat bukti, sehingga unsur kemanfaatannya masih tetap ada, yaitu untuk mempercepat proses pendaftaran tanah oleh masyarakat, akan tetapi kerugiannya adalah pengurangan alat bukti ketika terjadi sengketa atas sertipikat tersebut.

Kata Kunci: Surat Edaran; Sistem Pendaftaran Tanah; Kedudukan Hukum; Urgensi
\end{abstract}

\begin{abstract}
Circular Letter of Minister of Agrarian Affairs and Spatial Planning/BPN No. No. 1756/15.I/IV/2016 on the Implementation Guidance of Land. Registry made with the excuse to facilitate the process of registration of the land. The circular letter raises issues, it is related to the legal position of the Circular Letter of the Minister of Agrarian Affairs and Spatial or BPN No. 1756/15.I/IV/2016 in the Land Registration System for the first time. The research method used by the writer is the normative research method using statute approach and theoretical approach. Circular Letter of the Minister of Agrarian Affairs and Spatial Planning/BPN No. 1756/15.I/IV/2016 on Guidelines for the Implementation of Land Registration in the registration system is not a statutory law, because it is not contained in the sequence of Law No. 12/2011, only binds in, other than that its existence also eliminates evidences, so that elements of its usefulness still exist, that is to accelerate the process of land registration by the community, but the loss is the reduction of evidence when there is a dispute over the certificate.
\end{abstract}

Keywords: Circular; Land Registration System; Legal Status; Urgency

\section{PENDAHULUAN}

Tanah merupakan salah satu hal yang sangat penting dalam kelangsungan hidup manusia. Tanah tersebut dapat dimanfaatkan untuk berbagai hal, contohnya membangun rumah untuk tempat tinggal, bercocok tanam untuk bahan makanan, dan lain sebagainya. Negara Indonesia merupakan negara agraris di mana setiap kegiatan yang dilakukan oleh sebagian besar rakyat Indonesia senantiasa membutuhkan dan melibatkan tanah. ${ }^{1}$ Tanah sendiri

1 Samun Ismaya. (2011). Pengantar Hukum Agraria. Yogyakarta: Graha Ilmu, h. 55. 
dibutuhkan oleh banyak orang untuk berbagai kebutuhan namun jumlahnya terbatas atau tidak bertambah atau tetap, sehingga tanah yang tersedia tidak mampu lagi memenuhi kebutuhan yang terus meningkat terutama kebutuhan akan tanah untuk membangun perumahan sebagai tempat tinggal, untuk pertanian serta untuk membangun berbagai fasilitas umum dalam rangka memenuhi tuntutan terhadap kemajuan di berbagai bidang kehidupan. ${ }^{2}$

Hubungan tanah dengan manusia adalah sangat erat, di mana tanah sebagai benda tetap, akan selalu utuh dan selalu abadi yang tidak akan musnah di permukaan bumi kecuali adanya hari akhir. Karena hal itu, maka setiap perbuatan hukum yang berhubungan dengan tanah, misalnya pengalihan hak atas tanah, diperlukan suatu instansi yang mengurusnya, seperti Camat/PPAT dan BPN, supaya tidak terjadinya peristiwa hukum dalam penggunaan hak atas tanah, seperti banyak terjadi di Indonesia. ${ }^{3}$

Pemerintah mengeluarkan Undang-Undang Nomor 5 Tahun 1960 tentang Peraturan Dasar Pokok-Pokok Agraria (Lembaran Negara Tahun 1960 Nomor 104 dan Tambahan Berita Negara Nomor 2043, selanjutnya disingkat UUPA). Undangundang tersebut dilahirkan berdasarkan Pasal 33 ayat (3) Undang-Undang Dasar 1945 (selanjutnya disingkat UUD 1945), mengatur hubungan hukum antara Bangsa Indonesia dengan bumi, air, luar angkasa dan kekayaan alam yang terkandung di dalamnya. ${ }^{4}$ Tujuannya untuk memberikan dasar hukum yang jelas bagi kepemilikan hak-hak atas tanah, di mana negara sebagai kekuasaan tertinggi atas rakyat, berkewajiban untuk: $:^{5}$ a) Mengatur dan menyelesaikan peruntukan, penggunaan, persediaan dan pemeliharaan bumi, air dan ruang angkasa; $b$ ) Menentukan dan mengatur hubungan-hubungan hukum antara orang dengan bumi, air dan ruang angkasa; c) Menentukan dan mengatur hubungan-

${ }^{3}$ Fahmi CMD Widodo. (2013). Hubungan Manusia dengan Tanah. Jakarta. Paper Administrasi dan Kebijakan Pertanahan, h. 1 .

${ }^{4}$ Ramadhana Muhammad. (2015). "Hambatan dan Solusi Dalam Pelaksanaan Proyek Operasi Nasional Agraria (Prona) Secara Gratis di Kota Malang (Studi di Kantor Pertanahan Kota Malang)". Jurnal Mahasiswa Hukum. Volume 4 Nomor 2, h. 3.

${ }^{5}$ Dian Retno Wulan. (2006). "Pelaksanaan Proyek Operasi Nasional (Prona) di Kabupaten Karanganyar". Doctoral Dissertation. Semarang: Program Pascasarjana Universitas Diponegoro, h. 12.
}

hubungan hukum antara orang-orang dan perbuatanperbuatan hukum yang menyangkut penguasaan bumi, air dan ruang angkasa dalam rangka mencapai sebesar-besarnya kemakmuran rakyat Indonesia. ${ }^{6}$

Ketetapan tersebut mengandung pengertian bahwa hal-hal yang menyangkut kepemilikan, penguasaan, dan penggunaan tanah harus diikuti dengan kegiatan pendaftaran tanah baik yang dimiliki oleh masyarakat maupun oleh Badan Hukum ke Kantor Pertanahan guna mendapatkan kepastian hukum hak atas tanah yang dikuasainya atau yang dimilikinya. $^{7}$

Menurut AP Parlindungan, pendaftaran berasal dari kata Cadaster (bahasa Belanda Kadaster) yaitu istilah untuk rekaman (record), menunjukan tentang luas, nilai, dan kepemilikan atau lain-lain alas hak terhadap suatu bidang tanah. selain itu pendaftaran berasal dari bahasa Latin Capilastrum yang berarti suatu register atau unit yang diperbuat untuk pajak tanah Romawi. Dalam artian yang tegas Cadaster adalah rekaman dari pada lahan-lahan, nilai daripada tanah dan pemegang haknya dan untuk kepentingan hukum lainnya (record) ${ }^{8}$

Selain itu isi dari UUPA salah satunya adalah tata cara pembuatan sertipikat tanah di Indonesia, seperti dasar hukum pendaftaran tanah objek pendaftaran tanah dan lain-lain, supaya adanya penertiban tentang penggunaan tanah, karena sering dijumpai pada masyarakat bahwa tidak tahu dan tidak paham tentang penggunaan hak atas tanah, yang mana hal itu merupakan suatu hal yang harus diketahui, dan memerlukan suatu pembuktian atau alat bukti yaitu sertipikat tanah yang menyatakan tanah itu adalah benar-benar miliknya. ${ }^{9}$ Untuk mewujudkan pendaftaran tanah sebagaimana diamanatkan dalam Pasal 19 UUPA tersebut maka Pemerintah menetapkan Peraturan Pemerintah Nomor 24 Tahun 1997 tentang Pendaftaran Tanah. ${ }^{10}$

Pendaftaran tanah untuk pertama kali dilaksanakan melalui pendaftaran secara sistematik

${ }^{6}$ ibid.

7 Wibowo Tunardy. "Macam-Macam Hak Penguasaan Atas Tanah". http://www.jurnalhukum.com/macam-macam-hakpenguasaan-atas-tanah/, diakses tanggal 10 September 2017.

8 A.P. Parlindungan. (2002). Pendaftaran Tanah di Indonesia. Bandung: Mandar Maju, h. 11.

9 Eko Sugitario. (2007). "Hubungan Hukum dan Politik", Jurnal Yustika. Volume 4, h. 2.

10 ibid. 
dan pendaftaran tanah secara sporadik. Pendaftaran tanah secara sistematik dilaksanakan atas prakarsa Badan Pertanahan Nasional yang didasarkan atas suatu rencana kerja jangka panjang dan rencana tahunan yang berkesinambungan. Pelaksanaannya dilakukan di wilayah-wilayah yang ditunjuk oleh Menteri. Sedangkan untuk wilayah-wilayah yang belum ditunjuk sebagai wilayah pendaftaran tanah secara sistematik, pendaftarannya dilaksanakan secara sporadik. Pendaftaran tanah secara sporadik dilaksanakan atas permintaan pihak yang berkepentingan yaitu pihak yang berhak atas obyek pendaftaran tanah yang bersangkutan. ${ }^{11}$

Dalam Surat Edaran Menteri Agraria dan Tata Ruang/BPN No. 1756/15.I/IV/2016 menginstruksikan: 1) Melakukan percepatan kegiatan pendaftaran tanah di seluruh Indonesia baik melalui dana pemerintah maupun dana swadaya masyarakat; 2) Dalam hal dasar penguasaan dan/atau alat bukti kepemilikan tanah masyarkat tidak lengkap atau sama sekali tidak mempunyai dasar penguasaan dan/atau bukti kepemilikan tanah agar dibuktikan dengan surat pernyataan tertulis tentang penguasaan fisik bidang tanah dengan itikad baik dari yang bersangkutan; 3 ) Itikad baik sebagaimana tersebut di atas dibuktikan sebagai berikut: a) Tidak ada keberatan dari pihak lain atas tanah yang dikuasai/tidak dalam sengketa; b) Tidak termasuk sebagai aset Pemerintah dan Pemerintah Daerah; c) Tidak termasuk dalam kawasan hutan; 4) Surat pernyataan sebagaimana dimaksud di atas dibuat dengan disaksikan paling sedikit 2 (dua) orang saksi dari lingkungan setempat yang tidak mempunyai hubungan keluarga dengan yang bersangkutan sampai dengan derajat kedua, baik dalam kekerabatan vertikal maupun horizontal yang menyatakan bahwa yang bersangkutan adalah benar sebagai pemilik dan menguasai bidang tanah tersebut: 5) Surat pernyataan tersebut dibuat berdasarkan keterangan yang sebenar-benarnya dan pihak yang membuat pernyataan bertanggung jawab baik secara perdata maupun pidana apabila di kemudian hari terdapat unsur-unsur ketidakbenaran dalam pernyataan dan bersedia sertipikatnya dibatalkan dan diproses hukum sesuai peraturan yang berlaku serta tidak melibatkan pihak lain; 6) Surat pernyataan

11 Boedi Harsono. (2013). Hukum Agraria Indonesia. Jakarta: Penerbit Universitas Trisakti, h. 87. sebagaimana tersebut di atas dibuat sesuai dengan lampiran surat ini. ${ }^{12}$

Dasar pertimbangan diterbitkannya Surat Edaran Menteri Agraria dan Tata Ruang/BPN No. 1756/15.I/ IV/2016 adalah untuk menjamin kepastian hukum atas hak tanah masyarakat dan untuk meningkatkan kesejahteraan masyarakat melalui pendaftaran tanah. Mengingat masih terdapat masyarakat yang menguasai tanah namun tidak memiliki buktibukti kepemilikan tanah (alas hak) secara lengkap dan bahkan sama sekali tidak mempunyai bukti kepemilikan sehingga terkendala dalam permohonan pendaftaran hak atas tanahnya. ${ }^{13}$

Dengan diterbitkanya Surat Edaran Menteri Agraria dan Tata Ruang/BPN No. 1756/15.I/ IV/2016 maka diharapkan akan mempermudah dan mempercepat proses pendaftaran tanah, seperti yang diulas pada artikel https://www.atrbpn.go.id/, salah satu syarat dalam mengurus sertipikat tanah ke Kementerian ATR/BPN adalah Surat Kepemilikan Tanah (SKT). SKT ini dikeluarkan oleh Kelurahan setempat. Menurut Menteri ATR/BPN Ferry Mursyidan Baldan, nantinya persyaratan ini akan dihapus BPN karena seringkali kepengurusannya memakan waktu lama. Masyarakat tidak bisa mendapatkan SKT dalam mengurus sertipikat di BPN, maka pemerintah akan proaktif dalam melakukan proses pengecekan. ${ }^{14}$

Dengan demikian, masyarakat dan BPN tidak perlu menunggu terbitnya SKT dari kelurahan. Dalam hal ini, Kementerian ATR/BPN 'jemput bola' ke masyarakat itu sendiri sehingga tidak ada hambatan. SKT itu sebetulnya menegaskan riwayat tanah. Pejabat lurah yang diangkat dan bukan dari daerah tersebut, paling sering berlaku di perkotaan. ${ }^{15}$

Pendaftaran tanah untuk pertama kalinya untuk tanah bekas hak milik adat dan tanah garapan, salah satu persyaratannya adalah mendapatkan surat rekomendasi dari Lurah/Camat perihal tanah yang

12 Nova Susanti. (2017). "Pendaftaran Tanah Pertama Kali, Berdasarkan Jual Beli di bawah Tangan di Kabupaten Padang Pariaman”. Tesis. Fakultas Hukum Program Magister Kenotariatan Universitas Andalas.

${ }^{13}$ Irma Devita. "Untuk Pensertifikatan Tanah Sudah Tidak Perlu Lagi SKT Dari Kelurahan”. https://irmadevita.com/2016/ untuk-pensertifikatan-tanah-sudah-tidak-perlu-lagi-skt-darikelurahan/, diakses pada tanggal 19 Mei 2017 pada pukul 10:0011.00 WIB.

\footnotetext{
${ }^{14}$ Irma Devita. https://irmadevita.com, ibid.

${ }^{15}$ Irma Devita. https://irmadevita.com, ibid.
} 
bersangkutan, yang menyatakan bahwa atas tanah tersebut belum pernah disertipikatkan serta riwayat pemilikan tanah dimaksud yang dilampirkan dengan Surat Riwayat Tanah. Dan pembuatan surat yang menyatakan bahwa tanah tersebut tidak dalam keadaan sengketa dari RT/RW/Lurah. Dengan dihapuskannya persyaratan SKT maka proses pendaftaran tanah bisa menjadi lebih cepat. Namun, harus dipahami juga oleh masyarakat bahwa tidak semua tanah-tanah yang belum bersertipikat tersebut berasal dari tanah bekas hak milik adat atau tanah girik, karena salah satu bentuk surat yang mungkin dipegang oleh masyarakat merupakan tanah-tanah bekas Hak Barat yang berasal sejak jaman Belanda, namun belum dikonversi pada saat ketentuan konversi tanah diberlakukan di tahun 1960. Tanah-tanah yang demikian biasanya masih berstatus tanah Eigendom, Eigendom Verponding, tanah Opstal, maupun tanah Erfpacht, yang tentunya proses pensertipikatannya akan berbeda dengan proses pensertipikatan tanah bekas hak milik adat tersebut. ${ }^{16}$

Berdasarkan latar belakang di atas dalam hal ini tentu saja terdapat kekosongan hukum, dikarenakan Surat Edaran Menteri Agraria dan Tata Ruang/BPN No. 1756/15.I/IV/2016 bukanlah merupakan aturan perundang-undangan sebagaimana yang terdapat dalam Undang-Undang No. 12 Tahun 2011.

\section{PERUMUSAN MASALAH}

Beranjak dari latar belakang sebagaimana yang sudah penulis uraikan di atas, maka dapat dirumuskan isu hukum atau permasalahan sebagai berikut, yaitu bagaimana kedudukan hukum Surat Edaran Menteri Agraria dan Tata Ruang/BPN No. 1756/15.I/IV/2016 dalam sistem pendaftaran tanah pertama kali.

\section{METODE PENELITIAN}

Penyusunan artikel ini menggunakan pendekatan masalah yuridis normatif, yaitu pendekatan perundang-undangan dan pendekatan teoritis.

\section{PEMBAHASAN}

Esensi Hukum Surat Edaran Menteri Agraria dan Tata Ruang/BPN No. 1756/15.I/IV/2016 dalam Sistem Pendaftaran Tanah Pertama Kali

\footnotetext{
${ }^{16}$ Administrator. (2017). "Pendaftaran Tanah". https://www. atrbpn.go.id/, diakses pada tanggal 19 Mei 2017 Pukul 10:0011:00 WIB.
}

Pasal 19 ayat (1) UUPA menentukan bahwa untuk menjamin kepastian hukum oleh pemerintah, maka pendaftaran tanah di seluruh wilayah Indonesia menurut ketentuan-ketentuan yang diatur dengan Peraturan Pemerintah, sehingga sifat pendaftaran tanah yang dilakukan oleh pemerintah memiliki sifat rechtkadaster, yang memiliki arti menjamin kepastian hukum.

Sedangkan Pasal 3 PP No. 24 Tahun 1997 menyatakan bahwa tujuan pendaftaran tanah adalah sebagai berikut: a) Untuk memberikan kepastian hukum dan perlindungan hukum kepada pemegang hak atas suatu bidang tanah, satuan rumah susun dan hak-hak lainnya yang terdaftar agar dengan mudah dapat membuktikan dirinya sebagai pemegang hak yang bersangkutan; b) untuk menyediakan informasi kepada pihak yang berkepentingan termasuk pemerintah agar dengan mudah dapat memperoleh data yang diperlukan dalam mengadakan perbuatan hukum mengenai bidang-bidang tanah dan satuan rumah susun yang terdaftar; c) Untuk terselenggaranya tertib administrasi pertanahan, pendaftaran tanah menurut Pasal 19 ayat (2) UUPA jo Pasal 1 ayat (1) PP No. 24 Tahun 1997 adalah rangkaian kegiatan yang dilakukan oleh pemerintah secara terus-menerus, berkesinambungan dan teratur yang meliputi pengumpulan, pengolahan pembukuan, dan penyajian serta pemeliharaan data fisik dan data yuridis, dalam bentuk peta dan daftar mengenai bidang-bidang tanah dan satuan-satuan rumah susun, pemberian surat tanda bukti haknya bagi bidang-bidang sudah ada haknya dan hak milik atas satuan rumah susun serta hak-hak tertentu yang membebaninya. ${ }^{17}$

Pasal 9 PP No. 24 Tahun 1997 menyatakan bahwa obyek pendaftaran tanah adalah bidang-bidang tanah yang dipunyai dengan hak milik, hak guna usaha, hak guna bangunan, dan hak pakai, tanah hak pengelolaan, tanah wakaf, hak milik atas satuan rumah susun, hak tanggungan, dan tanah negara. Sistem pendaftaran tanah memiliki dua sistem, yaitu sistem pendaftaran akta (registration of deeds), dan sistem pendaftaran hak (registration of titles), yang mana pemilihan sistem pendaftaran ini menentukan apa yang didaftar,

17 Ryan Alfi Syahri. (2014). "Perlindungan Hukum Kepemilikan Hak Atas Tanah". Jurnal Ilmu Hukum Legal Opinion. Edisi 5 Volume 2, h. 2. 
bentuk penyimpanan dan penyajian data yuridisnya serta bentuk tanda bukti-bukti haknya. ${ }^{18}$

Sistem pendaftaran akta, Petugas Pendaftaran Tanah (selanjutnya disebut dengan PPT) bersifat pasif atau tidak melakukan pengujian data yang disebut dalam akta yang didaftar, sistem pendaftaran ini melakukan pendaftaran terhadap dokumendokumen yang membuktikan diciptakannya hak yang bersangkutan dan dilakukannya hak tersebut kemudian hari, ${ }^{19}$ sebelum berlakunya UUPA, Indonesia menganut sistem pendaftaran ini. Pendaftaran hak adalah penciptaan hak baru dan perbuatan-perbuatan hukum yang menimbulkan perbuatan-perbuatan hukum yang menimbulkan perubahan kemudian, tetapi dalam penyelenggaraan pendaftarannya bukan aktanya yang didaftar mengenai haknya yang diciptakan dan perubahanperubahannya kemudian. Akta hanya merupakan sumber datanya. ${ }^{20}$ Sistem ini tampak dengan adanya Buku Tanah sebagai dokumen yang memuat data yuridis dan data fisik yang dihimpun dan disajikan serta diterbitkannya sertipikat sebagai surat tanda bukti atas hak atas tanah yang didaftar. ${ }^{21}$

Konsep ideal sistem pendaftaran tanah yang digunakan UUPA dan PP No. 24 Tahun 1997 adalah stelsel publisitas negative (berunsur positif). ${ }^{22} \mathrm{Hal}$ ini dapat diketahui bahwa karakter negatif tersebut disebutkan secara tegas pada penjelasan Pasal $32 \mathrm{PP}$ No. 24 Tahun 1997 yang berbunyi: Pendaftaran tanah yang penyelenggaraannya diperintahkan oleh UUPA tidak menggunakan sistem publikasi positif, yang kebenaran data yang disajikan dijamin oleh negara, melainkan menggunakan sistem publikasi negatif". Dengan begitu karena stelsel negatif tentang register atas pendaftaran tanah yang berlaku di Indonesia, maka terdaftarnya nama seseorang di dalam register bukanlah berarti absolut menjadi pemilik tanah tersebut, apabila ketidakabsahannya dapat dibuktikan pihak lain. Berunsur Positif adalah adanya

\footnotetext{
${ }^{18}$ Boedi Harsono. (2008). Hukum Agraria Indonesia: Sejarah Pembentukan Undang-Undang Pokok Agraria, Isi dan Pelaksanaannya. Jakarta: Djambatan, h. 76.

${ }^{19}$ Urip Santoso. (2011). Pendaftaran dan Peralihan Hak Atas Tanah. Jakarta: Kencana Prenadia Media Group, h. 32.

${ }^{20}$ Boedi Harsono, op.cit., h. 77.

${ }^{21}$ Urip Santoso, op.cit., h. 31-32.

${ }^{22}$ Mudjiono. (1999). Politik Agraria Nasional-Hubungan Manusia Dengan Tanah Yang Berdasarkan Pancasila. Yogyakarta: GAMA University Press, h. 30-34.
}

peran aktif pelaksana pendaftaran, ciri-ciri sistem negatif bertendensi positif dalam hal pendaftaran tanah seperti yang dianut UUPA adalah sebagai berikut: $^{23}$ 1) Nama pemilik tanah yang tercantum dalam daftar buku tanah adalah pemilik tanah yang benar dan dilindungi hukum, dan merupakan tanda bukti hak yang tertinggi; 2) Setiap peristiwa balik nama melalui peneliti seksama, syarat-syarat dan prosedur berdasarkan asas keterbukaan (openbaar heidsbeginsel); 3) Setiap bidang tanah (persil) batas-batasnya diukur dan digambar dalam peta pendaftaran dengan skala 1:1.000. Ukuran tersebut memungkinkan untuk meneliti kembali batas-batas persil bila kemudian hari terjadi sengketa batas; 4) Pemilik tanah yang tercantum dalam buku tanah dan sertipikat masih dapat diganggu-gugat melalui Pengadilan Negeri oleh BPN; 5) Pemerintah tidak menyediakan dana untuk pembayaran ganti kerugian kepada masyarakat karena kesalahan administrasi pendaftaran tanah. Masyarakat yang dirugikan dapat menuntut melalui Pengadilan Negeri untuk mendapatkan haknya. ${ }^{24}$

Pendaftaran tanah, ada dua macam cara, yaitu pendaftaran tanah secara sistematik dan pendaftaran tanah secara sporadik. Pendaftaran tanah secara sistematik adalah kegiatan pendaftaran tanah untuk pertama kali atas prakarsa Pemerintah, yang dilakukan secara serentak dan meliputi semua objek pendaftaran tanah yang belum di daftar dalam wilayah atau bagian wilayah suatu Desa/ Kelurahan. Pendaftaran tanah secara sporadik adalah kegiatan pendaftaran tanah untuk pertama kali yang dilaksanakan atas permintaan pihak yang berkepentingan, mengenai satu atau beberapa obyek pendaftaran tanah dalam wilayah atau bagian wilayah suatu Desa/Kelurahan secara individual atau massa. ${ }^{25}$

Surat Edaran Menteri Agraria dan Tata Ruang/ Kepala Badan Pertanahan Nasional No. 1756/15.I/ UV/2016 yang isinya menyampaikan edaran kepada seluruh Kantor Pertanahan untuk menyederhanakan proses pendaftaran tanah dengan tujuan untuk menjamin kepastian hukum atas hak atas tanah masyarakat dan untuk meningkatkan kesejahteraan

${ }^{23}$ Suardi. (2005). Hukum Agraria. Jakarta: Badan Penerbit IBLAM, h. 151-152.

24 ibid.

${ }^{25}$ Aminuddin Salle, et.al. (2010). Hukum Agaria. Makassar: AS Publishing, h. 251. 
masyarakat melalui pendaftaran tanah. Mengingat banyak masyarakat yang menguasai tanah akan tetapi tidak memiliki bukti-bukti kepemilikan tanah secara lengkap bahkan sama sekali sehingga terkendala dalam permohonan pendaftaran hak atas tanahnya. Penyederhanaan yang dituangkan dalam Surat Edaran tersebut, adalah dihapusnya SKT dari Kelurahan setempat dikarenakan dalam pengurusannya membutuhkan waktu yang lama, adapun SKT merupakan bukti kepemilikan tanah karena menunjukkan riwayat kepemilikan tanah. ${ }^{26}$

\section{Surat Edaran Menteri Agraria dan Tata Ruang/BPN No. 1756/15.I/IV/2016 dalam Teori Perbandingan Hukum}

Hukum Tanah di Negara Bagian New South Wales-Australia, pengertian Tanah menurut Conveyancing Act 1919 No. 6, adalah Land includes tenements and hereditaments, corporeal and incorporeal, and every estate and interest therein whether vested or contingent, freehold or leasehold, and wheter at law or in equity. Sedangkan dalam Real Property Act 1900 No. 25 dinyatakan definisi tanah adalah Land messuages tenements, and hereditaments corporeal and incorporeal of every kind and description or any estate or interest therein, together with all paths, passages, ways, watercourses, liberties, privileges, easements, platations, gardens, mines, minerals, quarries, and all trees and timber thereon or thereunder lying or being unless any such are specially excepted. ${ }^{27}$

Hukum Tanah Australia bersumber pada English Common menggunakan asas Accessie (Perlekatan), sedangkan Hukum Tanah Nasional di Indonesia yang bersumber pada Hukum Adat mengunakan Asas Horizontale Scheiding (Pemisahan Horizontal) ${ }^{28}$

Australia melaksanakan pendaftaran hak atas tanah (registration of titles) dan sistemnya positif dengan memungut "insurance funds" (dana asuransi ...\% dari harga tanah), sekali subyek dan obyek atas tanah didaftar (melalui pemeriksaan yang teliti atas subyek dan obyek tanah) di Kantor Pertanahan (Land

\footnotetext{
${ }^{26}$ Irma Devita. https://irmadevita.com, op.cit.

${ }^{27}$ Solichin Ristiarto. "Pengaturan Tanah Ulayat di Indonesia dan Australia". http://www.academia.edu/, diakses pada tanggal 15 Agustus 2017.

${ }^{28}$ Indra Gumilar. (2017). "Sistem Torrens". https://www. slideshare.net/mobile/igum26/sistem-torrens/, diakses tanggal 13 Mei 2017 Pukul 09:00-10:00 WIB.
}

Title Office) maka tidak ada yang bisa menggugatnya. Setiap pemegang hak yang akan memperlakukan haknya kepada pihak ketiga, hak tersebut harus didaftar dalam "REGISTER BOOK”. Hak yang telah didaftar dalam register book tersebut oleh "Register Generaal" atau pejabat pendaftaran hak, dibuatkan sertipikat hak rangkap 2 (dua). Sertipikat hak rangkap 2 (dua) yang satu diberikan kepada yang lain dijadikan bagian dari "REGISTER BOOK". Sertipikat untuk pemohon dianggap sebagai alat bukti mutlak, dalam arti pemegang hak tidak dapat diganggu gugat oleh siapapun, dalam "Real Property $A c t$ " (UU Pertanahan) sistem Torrens ini mengatur perbuatan hukum "oroginair" (first registration $=$ pendaftaran pertama) maupun perbuatan hukum derivatif lainnya seperti jual beli mortage (hak tanggungan), hibah, dan sebagainya. Untuk penyelenggaraan transaksi di bidang pertanahan, masyarakat bebas untuk memilih, apakah akan menggunakan jasa dari "solicitor", "landbroker", atau mengerjakannya sendiri. Pendaftaran karena transaksi atau pengalihan hak kepada "REGISTER GENERAAL" adalah kewajiban dalam rangka "The Maintenance of Public Register" atau pemeliharaan data pendaftaran tanah. ${ }^{29}$

Hal tersebut berbeda dengan sistem pendaftaran tanah di Indonesia yang bersumber dari hukum adat dengan asas pelekatan horizontal dengan menggunakan sistem negatif akan tetapi bertendensi ke positif. Berbeda dengan alat bukti dalam pendaftaran tanah di Australia yang sifatnya mutlak dan memiliki asas pelekatan tanah security of title, pengadaan dari keterlambatan dan pembiayaan yang berlebihan penyederhanaan atas hak, ketelitian, maka di Indonesia memiliki alat bukti berupa sertipikat yang sifatnya kuat tetapi tidak mutlak sedang asas pendaftaran tanahnya sederhana aman, terjangkau, mutakhir, dan terbuka. Jenis pendaftaran hak yang dilakukan oleh kedua negara tersebut sama-sama pendaftaran hak. Sedangkan para pihak yang terkait dengan pendaftaran tanah di Indonesia hanya dua pihak saja, yaitu Pejabat Pembuat Akta Tanah (PPAT) dan individu, sedangkan pada Australia terdapat tiga pihak, yaitu Solicitor, Landbroker, dan Individu. Sedangkan untuk jaminan pemerintah Indonesia belum menjamin kebenaran data fisik dan yuridis dalam sertipikat. Sedangkan pemerintah Australia

29 ibid. 
menjaminnya. Perbedaan juga ada pada status tanah, di mana di Indonesia terdapat Tanah Negara, Tanah Adat, Tanah Hak, dan Tanah Swapraja (Sultan), sedangkan di Australia Tanah Milik Raja, Tanah Cadangan Milik Raja, Tanah Aborigin, dan Tanah Kosong Milik Raja. Jika ada gugatan, di Indonesia bisa beralih ke pemilik sebenarnya, sedangkan di Australia tidak, akan tetapi mendapatkan ganti kerugian. ${ }^{30}$

Perbedaan terakhir adalah di Indonesia tidak ada kewajiban mendaftarkan peralihan hak pada Kantor Pertanahan, sedangkan pada Australia pendaftaran karena transaksi atau pengalihan hak kepada "REGISTER GENERAL" adalah kewajiban dalam rangka "The Maintenance of Public Register atau pemeliharaan data pendaftaran tanah. Pada Australia SKT tidak perlu untuk ada, sebab pada sistem pendaftaran tanah yang ada di Australia menggunakan sistem torrens, hal ini berarti sistem publikasinya merupakan sistem yang positif, sehingga suatu sertipikat dianggap sebagai hal yang benar dan mutlak. Tidak boleh ada orang yang mengajukan gugatan terhadap sertipikat tersebut. Berbeda halnya apabila di Indonesia yang menggunakan sistem negatif yang bertendensi positif, di mana gugatan terhadap sertipikat dapat dilakukan, sehingga dibutuhkan SKT sebagai salah satu bukti. Surat Edaran terkait penghapusan SKT di dalam Sistem Pendaftaran Tanah, tidak ada, sebab di Australia Sistem yang digunakan adalah Sistem Positif sehingga tidak memerlukan SKT sebagai pembuktian dalam sengketa yang menyangkut tentang tanah. ${ }^{31}$

\section{Surat Edaran Menteri Agraria dan Tata Ruang/ BPN No. 1756/15.I/IV/2016 dalam Tata Hierarki Perundang-undangan}

Adapun landasan hukum terkait SKT terdapat dalam Pasal 76 ayat (3) Peraturan Menteri Agraria No. 3 Tahun 1997, yang berbunyi dalam hal buktibukti mengenai kepemilikan tanah sebagaimana dimaksud pada ayat (1) dan (2) tidak ada maka permohonan tersebut harus disertai dengan surat pernyataan dari pemohon. Sementara Surat Edaran Menteri Agraria dan Tata Ruang/BPN No. 1756/15.I/ IV/2016 menyebutkan tentang petunjuk pelaksanaan

$$
\begin{aligned}
& { }^{30} \text { ibid. } \\
& 31 \text { ibid. }
\end{aligned}
$$

pendaftaran tanah masyarakat dalam hal ini pendaftaran tanah pertama kali bagi pemohon yang hanya memiliki sebagian alat bukti kepemilikan tanah dan bagi pemohon yang sama sekali tidak memiliki bukti kepemilikan tanah sehingga memangkas rantai birokrasi yang rumit dan panjang, dengan harapan pemohon sudah tidak memerlukan lagi SKT yang biasanya dikeluarkan oleh kantor Kecamatan/kantor Kelurahan. ${ }^{32}$

Surat Edaran adalah surat yang isinya menyangkut pemberitahuan secara resmi di dalam instansi, lembaga, atau organisasi. Surat ini berisikan penjelasan mengenai suatu kebijakan baru dari pimpinan instansi, berisikan penjelasan mengenai suatu hal. ${ }^{33}$ Macam-macam jenis Surat Edaran, yaitu: 1) Surat Edaran Terbatas yaitu surat yang biasanya ditujukan dari satu organisasi atau instansi kepada para anggotanya saja; 2) Surat Edaran Tidak Terbatas, yaitu surat yang ditujukan kepada masyarakat luas. Sedangkan macam Surat Edaran: a) Surat Edaran Pemerintah, yaitu adanya pemberitahuan kepada seluruh rakyat Indonesia yang bersifat nasional, misalnya mengenai perayaan hari besar nasional, mengenai sensus penduduk, mengenai pemilu; b) Surat Edaran dari instansi pemerintah adalah pemberitahuan dan penjelasan tentang pelaksanaan peraturan di lingkungan instansi tersebut, misalnya Departemen Pendidikan Nasional membuat edaran tentang petunjuk kenaikan kelas, petunjuk Ujian Nasional, penetapan waktu ujian, petunjuk penentuan pelaksanaan ujian, petunjuk penilaian ujian, serta petunjuk kelulusan ujian; c) Surat Edaran dari perusahaan terdiri atas: surat edaran khusus, yaitu pemberitahuan sesuatu yang ditujukan untuk satu lingkungan tertentu, surat edaran umum adalah surat edaran untuk memperkenalkan jasa perusahaan dan hasil produk dari perusahaan ke seluruh lapisan masyrakat. Dengan demikian, maka fungsi surat edaran adalah untuk menyampaikan informasi atau pengumuman kepada orang banyak yang sifatnya tidak rahasia. ${ }^{34}$

32 Jimly Asshiddiqie dan M. Ali Safa'at. (2006). Theory Hans Kelsen tentang Hukum. Cet. 1. Jakarta: Sekretariat Jenderal dan Kepaniteraan Mahkamah Konstitusi RI, h. 110.

${ }^{33}$ Jesica Lestari, dkk. "Perbedaan Surat Edaran, Peraturan Menteri dan Undang-Undang", http://jesicalestari29.blogspot. co.id/2017/06/perbedaan-surat-edaran-peraturan-mentri.html, diakses pada tanggal 13 Mei 2017 pukul 09:00-10:00 WIB.

${ }^{34}$ ibid. 
Peraturan Menteri adalah salah satu instrumen hukum yang keberadaannya diperlukan dalam melaksanakan peraturan perundang-undangan di atasnya yang secara jelas mendelegasikan Kemandirian menteri untuk mengeluarkan suatu peraturan atas dasar suatu kebijakan, bukan atas dasar pemberian kewenangan mengatur peraturan di atasnya akan tetapi pada tertib penyelenggaraan pemerintahan yang diinginkan dalam rangka mempermudah pelaksanaan administrasi atau kepentingan prosedural lainnya. Sehingga baik Peraturan Menteri ataupun Surat Edaran memiliki pengertian yang sama dan kedudukan yang sama oleh karena itulah maka yang berlaku adalah asas lex posterior derogat legi priori di mana aturan hukum yang baru mengalahkan aturan hukum yang lama, sehingga Surat Edaran mengalahkan Peraturan Menteri, sebab Surat Edaran dikeluarkan pada tahun 2016 sedangkan Peraturan Menteri dikeluarkan pada tahun 1997. ${ }^{35}$

Undang-Undang Nomor 12 Tahun 2011 tentang Pembentukan Peraturan Perundang-undangan terkait tata hirarki Aturan Perundang-undangan yang dituangkan di dalam Pasal 7 adalah: a) Undang-Undang Dasar 1945; b) Ketetapan Majelis Permusyawaratan Rakyat; c) Undang-Undang/ Peraturan Pemerintah Pengganti Undang-Undang; d) Peraturan Pemerintah; e) Peraturan Presiden; f) Peraturan Daerah Provinsi, dan g) Peraturan Daerah Kabupaten/Kota. Berdasarkan tata aturan perundangundangan tersebut di atas, maka jelaslah bahwa baik Surat Edaran Menteri Agraria dan Tata Ruang/BPN No. 1756/15.I/IV/2016 maupun Peraturan Menteri Agraria No. 3 Tahun 1997, keduanya tidak terdapat di dalam aturan perundang-undangan. ${ }^{36}$

Peraturan Menteri atau Surat Edaran diatur dalam Pasal 8 ayat (1) UU No. 12 Tahun 2011 tentang Pembentukan Peraturan Perundang-undangan, selanjutnya disebut dengan UU No. 12 Tahun 2011, yang menegaskan: bahwa jenis peraturan perundangundangan selain yang dimaksud dalam Pasal 7 ayat (1) mencakup peraturan yang ditetapkan oleh Majelis Permusyawaratan Rakyat, Dewan Perwakilan Rakyat,

\footnotetext{
35 ibid.

${ }^{36}$ Bilal Dewansyah. (2014). "Kedudukan Peraturan Menteri dalam Hirarki Peraturan". https://www.hukumonline.com/klinik/ detail/lt5264d6b08c174/kedudukan-peraturan-menteri-dalamhierarki-peraturan-perundang-undangan, diakses pada tanggal 13 Mei 2018 pada Pukul 09:00-10:00 WIB.
}

Dewan Perwakilan Daerah, Mahkamah Agung, Mahkaman Konstitusi, Badan Pemeriksa Keuangan, Komisi Yudisial, Bank Indonesia, Menteri, Badan, Lembaga, atau Komisi yang setingkat yang dibentuk dengan Undang-Undang atau Pemerintah atas perintah Undang-Undang, Dewan Perwakilan Rakyat Daerah Provinsi, Gubernur, Dewan Perwakilan Rakyat Daerah Kabupaten/Kota, Bupati/Walikota, Kepala Desa atau yang setingkat. Walaupun ketentuan di atas tidak menyebut secara tegas jenis peraturan peraturan perundang-undangan berupa "Peraturan Menteri", namun frase "...peraturan yang ditetapkan oleh ... menteri ...." di atas, mencerminkan keberadaan Peraturan Menteri sebagai salah satu jenis peraturan, dengan demikian, Peraturan Menteri setelah berlakunya UU No. 12 Tahun 2011 tetap diakui keberadaannya. ${ }^{37}$

Pasal 8 ayat (2) UU No. 12 Tahun 2011 menyatakan tentang kekuatan mengikat Peraturan Menteri tersebut, yaitu: Peraturan perundangundangan sebagaimana dimaksud pada ayat (1) diakui keberadaannya dan mempunyai kekuatan hukum mengikat sepanjang diperintahkan oleh Peraturan Perundang-undangan yang lebih tinggi atau dibentuk berdasarkan kewenangan. Dalam UU No. 10 Tahun 2004 tidak dikenal peraturan perundang-undangan yang dibentuk atas dasar kewenangan, termasuk dalam hal Peraturan Menteri. Peraturan Menteri yang dibentuk tanpa adanya pendelegasian dari peraturan perundang-undangan yang lebih tinggi sebelum berlaku UU No. 12 Tahun 2011, dikenal secara teoritik sebagai peraturan kebijakan (beleidregels), yaitu suatu keputusan pejabat administrasi negara yang bersifat mengatur dan secara tidak langsung bersifat mengikat umum namun bukan peraturan perundang-undangan. ${ }^{38}$ Karena bukan peraturan perundang-undangan, peraturan kebijakan tidak dapat diuji oleh Mahkamah Agung yang memiliki kewenangan menguji peraturan perundang-undangan di bawah undang-undang terhadap undang-undang. Dengan adanya ketentuan Pasal 8 ayat (2) UU No. 12 Tahun 2011, maka tidak lagi perbedaan antara Peraturan Menteri yang merupakan peraturan

\footnotetext{
37 ibid.

38 Bagir Manan dan Kuntara Magnar. (1987). Peranan Peraturan Perundang-undangan dalam Pembinaan Hukum Nasional. Bandung: Armico, h. 13.
} 
perundang-undangan dengan Peraturan Menteri yang merupakan aturan kebijakan.

Kedudukan Peraturan Menteri yang telah dibentuk sebelum berlakunya UU No. 12 Tahun 2011, tetap berlaku sepanjang tidak dicabut atau dibatalkan. Namun demikian, terdapat dua jenis kedudukan Peraturan Menteri yang dibentuk sebelum berlakunya UU No. 12 Tahun 2011.

Pertama, Peraturan Menteri yang dibentuk atas dasar perintah peraturan perundang-undangan yang lebih tinggi, berkualifikasi sebagai peraturan perundang-undangan. ${ }^{39}$

Kedua, Peraturan Menteri yang dibentuk bukan atas dasar perintah peraturan perundangundangan yang lebih tinggi (atas dasar kewenangan), berkualifikasi sebagai aturan kebijakan. Hal ini disebabkan UU No. 12 Tahun 2011 berlaku sejak tanggal diundangkan (vide Pasal 104 UU No. 12 tahun 2011), sehingga adanya Peraturan Menteri yang dibentuk sebelum tanggal diundangkan UU No. 12 Tahun 2011 masih tunduk berdasarkan ketentuan undang-undang yang lama (UU No. 10 Tahun 2004). Konsekuensinya, hanya Peraturan Menteri kategori pertama di atas yang dapat dijadikan obyek pengujian Mahkamah Agung. ${ }^{40}$

Selanjutnya kedudukan Peraturan Menteri yang dibentuk setelah berlakunya UU No. 12 Tahun 2011, baik yang dibentuk atas dasar perintah peraturan perundang-undangan yang lebih tinggi maupun yang dibentuk atas dasar kewenangan di bidang urusan pemerintahan tertentu yang ada pada menteri, berkualifikasi sebagai peraturan perundang-undangan. Dengan demikian, Peraturan Menteri tersebut memiliki kekuatan hukum yang bersifat mengikat umum dan dapat dijadikan objek pengujian pada Mahkamah Agung, apabila dianggap bertentangan dengan undang-undang.

Sehingga berdasarkan teori tata hirarki perundangundangan, maka Surat Edaran tersebut tidak termasuk di dalam tata urutan peraturan perundang-undangan, sebab dibuat hanya berdasarkan dari kewenangan pihak yang membuatnya, oleh sebab itulah di dalam sistem pendaftaran tanah Surat Edaran tersebut hanya dapat diterapkan kepada instansi yang berada di bawah Menteri Agraria dan Tata Ruang/BPN saja.

\footnotetext{
39 ibid.

40 ibid.
}

Sehingga Surat Edaran tersebut di dalam Sistem Pendaftaran Tanah, bukanlah merupakan sesuatu yang utama, sebab tidak dapat diterapkan kepada semua pihak dalam sistem pendaftaran tanah. ${ }^{41}$

\section{Pembuktian dalam Kasus Sengketa Tanah setelah Terbitnya Surat Edaran Menteri Agraria dan Tata Ruang/BPN No. 1756/15.I/IV/2016}

Bagi para pemohon yang mendaftarkan tanahnya untuk pertama kali, bagi pemohon yang memiliki sebagian atau tidak sama sekali bukti kepemilikan diharapkan nantinya bisa mendapat perlindungan hukum terhadap pelaksanaan perundang-undangan yang ada. Teori Perlindungan Hukum ini digunakan untuk menjelaskan bagaimana urgensi Surat Edaran Menteri Agraria dan Tata Ruang/BPN No. 1756/15.I/ IV/2016 nantinya bisa berfungsi dengan baik atau tidak dalam memberikan perlindungan hukum bagi para pemohon pendaftaran tanah pertama kali.

PP No. 24 Tahun 1997 tentang Pendaftaran Tanah, walaupun surat di bawah tangan tidak memiliki kekuatan hukum akan tetapi untuk dapat dijadikan sebagai alas dalam penerbitan sertipikat. Pendaftaran tanah untuk pertama kali adalah "kegiatan pendaftaran tanah yang dilakukan terhadap obyek pendaftaran tanah yang belum didaftar berdasarkan Peraturan Pemerintah Nomor 10 Tahun 1961 tentang Pendaftaran Tanah atau Peraturan Pemerintah ini". Kegiatan pendaftaran tanah untuk pertama kali menurut ketentuan Pasal 12 ayat (1) PP No. 24 Tahun 1997: a) pengumpulan dan pengolahan data fisik; b) pembuktian hak dan pembukuannya; c) penerbitan sertipikat; d) penyajian data fisik dan data yuridis; e) penyimpanan daftar umum dan dokumen. 1) Pendaftaran Tanah secara Sistematik dan 2) Pendaftaran Tanah Secara Sporadik. Para pihak yang terlibat dalam penerbitan sertipikat adalah pihak pemohon, para pemilik tanah maupun pihak instansi yang terkait untuk memperoleh penjelasan dan surat-surat sebagai alas hak yang berhubungan dengan permohonan sertipikat tersebut. Penjelasan yang diberikan pemohon baik lisan maupun tertulis dari pihak terkait memiliki peluang untuk terjadinya pemalsuan, daluwarsa bahkan ada kalanya tidak

41 Hasanuddin Hasim. (2017). "Hierarki Peraturan Perundang-undangan Negara Republik Indonesia Sebagai Suatu Sistem". Madani Legal Review. Volume 1 Nomor 2 Desember, h. $130-140$. 
benar atau fiktif sehingga timbul sertipikat cacat hukum. ${ }^{42}$

Surat pernyataan penguasaan fisik yang dibuatkan oleh pemohon pendaftaran tanah berisi: ${ }^{43}$ 1) Fisik tanahnya secara nyata dikuasai dan digunakan sendiri oleh pihak yang mengaku atau secara nyata tidak dikuasai, tetapi digunakan pihak lain secara sewa atau bagi hasil atau dengan bentuk hubungan perdata lainnya; 2) Tanahnya sedang atau tidak dalam keadaan sengketa. Apabila penandatangan memalsukan isi surat pernyataan, bersedia dituntut di muka hakim secara pidana maupun perdata karena memberikan keterangan palsu.

Pasal 1 angka 20 PP No. 24 Tahun 1997 yang dimaksud Sertipikat adalah Surat tanda bukti hak sebagaimana dimaksud dalam Pasal 19 ayat (2) huruf c UUPA untuk hak atas tanah, hak pengelolaan, tanah wakaf, hak milik atas satuan rumah susun dan hak tanggungan yang masing-masing sudah dibukukan dalam buku tanah yang bersangkutan. Pasal 19 UUPA, sertipikat adalah surat tanda bukti hak yang berlaku sebagai alat pembuktian yang kuat, maka hal ini diulang lagi penegasannya dalam Pasal 39, namun dengan satu klausula bahwa hal ini berlaku selama belum berhasil dibuktikan, sebaliknya yang oleh sementara pihak dinilai dapat melemahkan kedudukan sertipikat sebagai alat bukti yang kuat. ${ }^{44}$

Dalam pembuktian hak lama berdasarkan penguasaan tanah dibuktikan berdasarkan pernyataan tertulis yang bersangkutan dan dikuatkan saksi-saksi, sebagaimana ditentukan dalam penjelasan Pasal 24 ayat (2) Peraturan Pemerintah Nomor 24 Tahun 1997 tentang Pendaftaran Tanah harus memenuhi syarat sebagai berikut: a) Penguasaan tanah yang digunakan secara nyata dengan itikad baik, selama atau lebih 20 (dua puluh) tahun berturut-turut; b) Penguasaan tanah tersebut dihormati dan tidak diganggu gugat oleh pihak lain; c) Penguasaan tersebut dikuatkan oleh saksi-saksi yang dipercaya; d) Bahwa untuk pendaftaran hak atas tanahnya harus diteliti terlebih dahulu oleh panitia A dan diumumkan sesuai ketentuan Pasal 26 Peraturan Pemerintah No. 24 Tahun 1997, serta dikeluarkan

${ }^{42}$ Ali Achmad Chomzah. (2003). Hukum Pertanahan Seri Hukum Pertanahan III-Penyelesaian Sengketa Hak Atas Tanah dan Seri Hukum Pertanahan IV-Pengadaan Tanah Instansi Pemerintah. Jakarta: Prestasi Pustaka, h. 18.

${ }^{43}$ Boedi Harsono, op.cit., h. 183.

${ }^{44}$ Ali Achmad Chomzah, op.cit., h. 122. surat keputusan pengakuan haknya oleh pejabat berwenang, adapun macam-macam alat bukti: ${ }^{45}$ 1) Grose Akta Hak Eigendom yang diterbitkan berdasarkan Overschrijvings Ordonantie (Staatsblad. 1834-27), yang telah dibubuhi catatan, bahwa hak eigendom yang bersangkutan dikonversi menjadi hak milik; 2) Grose Akta Hak Eigendom yang diterbitkan berdasarkan Overschrijvings Ordonantie (Staatsblad. 1834-27), sejak berlakunya UUPA sampai tanggal pendaftaran tanah dilaksanakan menurut PP Nomor 10 Tahun 1961 di daerah yang bersangkutan; 3) Surat tanda bukti Hak Milik yang diterbitkan berdasarkan Peraturan Swapraja yang bersangkutan; 4) Sertipikat Hak Milik yang diterbitkan berdasarkan Peraturan Menteri Agraria Nomor 9 Tahun 1959; 5) Surat Keputusan Pemberian Hak Milik dari Pejabat yang berwenang, baik sebelum ataupun sejak berlakunya UUPA, yang tidak disertai kewajiban untuk mendaftarkan hak yng diberikan tetapi telah dipenuhi semua kewajiban yang disebut didalamnya; 6) Akta Pemindahan yang dibuat yang di bawah tangan dibubuhi tanda kesaksian oleh Kepala Adat/Kepala Desa/Kelurahan yang dibuat sebelum berlakunya Peraturan Pemerintah ini; 7) Akta Pemindahan Hak Atas Tanah yang dibuat oleh PPAT, yang tanahnya belum dibukukan; 8) Akta Ikrar Wakaf/Surat Ikrar Wakaf yang dibuat sebelum atau sejak dimulai dilaksanakan Peraturan Pemerintah Nomor 28 Tahun 1977; 9) Risalah lelang yang dibuat oleh Pejabat Lelang yang berwenang yang tanahnya belum dibukukan; 10) Surat Penunjukan atau Pembelian kavling tanah pengganti tanah yang diambil oleh Pemerintah atau Pemerintah Daerah; 11) Petuk Pajak Bumi/Landrente, girik, pipil, kekitir, dan Verponding Indonesia sebelum berlaku Peraturan Pemerintah No. 10 Tahun 1961; 12) Surat Keterangan Riwayat Tanah yang pernah dibuat oleh Kantor Pelayanan Pajak, Bumi dan Bangunan; 13) Lain-lain bentuk alat pembuktian tertulis dengan nama apapun juga sebagaimana dimaksud dalam Pasal II, Pasal VI, dan Pasal VII Ketentuan-Ketentuan Konversi UUPA. ${ }^{46}$

Pasal 24 ayat (1) PP No. 24 Tahun 1997 yang menyebutkan "Untuk keperluan pendaftaran hak, hak atas tanah yang berasal dari konversi hak-hak lama

${ }^{45}$ Muhammad Yamin Lubis. (2011). Pencabutan Hak, Pembebasan dan Pengadaan Tanah. Bandung: Mandar Maju, h. 221-223.

46 ibid. 
dibuktikan dengan alat-alat bukti mengenai adanya hak tersebut berupa bukti-bukti tertulis, keterangan saksi dan atau pernyataan yang bersangkutan yang kadar kebenarannya oleh Panitia Ajudikasi dalam pendaftraan tanah secara sistematik atau oleh Kepala Kantor Pertanahan dalam pendaftaran tanah secara sporadik, diangggap cukup untuk mendaftar hak, pemegang hak, dan hak-hak pihak lain yang membebaninya". ${ }^{47}$

Pasal 24 ayat (2) PP No. 24 Tahun 1997 menyebutkan "Dalam hal tidak atau tidak lagi tersedia secara lengkap alat-alat pembuktian sebagaimana dimaksud pada ayat (1), pembukuan hak dapat dilakukan berdasarkan kenyataan penguasaan fisik bidang tanah yang bersangkutan selama 20 (dua puluh) tahun atau lebih secara berturut-turut oleh pemohon pendaftaran dan pendahulu-pendahulunya dengan syarat: a) Penguasaaan tersebut dilakukan dengan itikad baik dan secara terbuka oleh yang bersangkutan sebagai yang berhak atas tanah, serta diperkuat oleh kesaksian orang yang dapat dipercaya; b) Penguasaan tersebut baik sebelum maupun selama pengumuman sebagaimana dimaksud dalam Pasal 26 tidak dipermasalahkan oleh masyarakat hukum adat atau Desa/Kelurahan yang bersangkutan ataupun pihak lannya, oleh sebab itulah SKT penting sebagai alat bukti di pengadilan apabila terjadi sengketa tanah dengan adanya dua sertipikat yang dimiliki oleh kedua belah pihak guna sebagai pembuktian pihak yang benar sebagai seorang pemilik, mengingat bahwa sistem yang dimiliki oleh Hukum Agraria Indonesia adalah sistem yang negatif dengan bertendensi positif, sehingga masih dimungkinkan untuk dilakukan gugatan oleh pihak yang dianggap memiliki tanah tersebut. ${ }^{48}$

Alat bukti yang berupa akta tertulis, baik akta tersebut merupakan akta yang di bawah tangan maupun akta notaris merupakan alat bukti yang sah dan dapat dipakai di Pengadilan, oleh karena itulah SKT dibuat untuk memberikan perlindungan hukum terhadap pihak yang dianggap memiliki hak atas tanah tersebut, yang mana haknya diambil oleh pihak lain. Dengan dihapuskannya SKT dalam

47 Benedicta Putri Dumatubun. (2016). "Pelaksanaan Pendaftaran Tanah Pertama Kali (Konversi Hak Milik Atas Tanah Adat) dalam Rangka Memberikan Jaminan Kepastian Hukum di Kabupaten Merauke”. Yogyakarta: Fakultas Hukum Universitas Atma Jaya Yogyakarta, h. 23.

$$
48 \text { ibid. }
$$

Surat Edaran sebagai persyaratan dari Pendaftaran Tanah, maka menghilangkan satu alat bukti yang dapat digunakan untuk menuntut hak, oleh sebab itu Surat Edaran ini tidak memenuhi unsur dalam Perlindungan Hukum, sebab sesungguhnya baik dalam Permenag No. 3 Tahun 1997 ataupun PP No. 24 Tahun 1997 menyatakan bahwa SKT sebagai alat bukti manakala terjadi sengketa. Hal tersebut penting sebab dalam pembuktian, alat bukti tertulis, baik akta notariil ataupun di bawah tangan merupakan bukti yang lebih kuat apabila dibandingkan dengan bukti saksi atau keterangan ahli. ${ }^{49}$

\section{Kemanfaatan SKT dalam Pendaftaran Tanah}

Latar belakang diterbitkannya Surat Edaran Menteri Agraria dan Tata Ruang/BPN No. 1756/15.I/ IV/2016 ialah untuk memudahkan proses pendaftaran tanah, mengingat beberapa masyarakat menganggap bahwa proses terumit dan terlama adalah pada tanah untuk permohonan SKT, akibatnya banyak masyarakat yang tidak memiliki Sertipikat Hak Atas Tanah. Berdasarkan hal tersebut, Menteri Agraria memiliki upaya untuk menyederhanakan proses pendaftaran tanah agar masyarakat dapat mengajukan permohonan Hak Atas Tanah dengan cara menerbitkan Surat Edaran dan menghapus syarat SKT didalamnya. Upaya yang dilakukan oleh Menteri Agraria tersebut membuahkan hasil. Dengan mempersingkat waktu dan prosedur tanpa adanya SKT, maka masyarakat yang berada di pedesaan dan selama ini tidak paham cara untuk mengajukan pendaftaran Hak Atas Tanah yang diperparah dengan kerumitan untuk permohonan SKT sebagai pembuktiannya sudah tidak ada lagi. ${ }^{50}$

Berdasarkan penjelasan di atas, Surat Edaran Menteri Agraria dan Tata Ruang/BPN No. 1756/15.I/ IV/2016 memiliki kemanfaatan untuk masyarakat, khususnya masyarakat pedesaan yang awam mengenai proses pendaftaran tanah, sehingga dapat dikatakan bahwa Surat Edaran Menteri Agraria tersebut telah memiliki kemanfaatan hukum, sebab kemanfaatannya kepada masyarakat yang jumlahnya lebih banyak dari jumlah pemegang hak yang

49 ibid.

${ }^{50}$ Ahmad Hasan Suyuthi. (2011). "Pelaksanaan Pendaftaran Tanah Secara Sistematik Melalui Program LMPDP (Land Management and Policy Development Project) di Kecamatan Ringinarum Kabupaten Kendal”. Skripsi. Semarang: Fakultas Hukum Universitas Negeri Semarang, h. 40. 
dirugikan. Akan tetapi, mengurangi pembuktian yang dibutuhkan oleh pemegang hak ketika ada pihak yang tidak berhak mengajukan gugatan sebagai pemegang Hak Atas Tanah yang sebenarnya.

\section{PENUTUP}

\section{Kesimpulan}

Surat Edaran Menteri Agraria dan Tata Ruang/BPN No. 1756/15.I/IV/2016 dalam sistem pendaftaran tanah pertama kali terkait dengan penghapusan SKT, dapat dikatakan bukan merupakan aturan perundang-undangan sebab tidak tercantum di dalam daftar aturan perundang-undangan yang berada di dalam Undang-Undang No. 12 Tahun 2011, sehingga Surat Edaran ini dalam Sistem Pendaftaran Tanah hanya dapat berlaku dan mengikat ke instansi/BPN yang berada di bawah kewenangan Kementerian Agraria dan Tata Ruang. Surat Edaran Menteri Agraria dan Tata Ruang/BPN No. 1756/15.I/ IV/2016 dalam sistem pendaftaran tanah pertama kali menghilangkan satu alat bukti yang dapat digunakan oleh masyarakat apabila merasa dirinya dirugikan karena hak miliknya berupa hak kepemilikan atas tanah diambil oleh orang yang tidak berhak secara paksa, sehingga tidak ada perlindungan hukum di dalamnya, akan tetapi apabila melihat kemanfaatannya pada proses pendaftaran tanah yang menjadi lebih sederhana dengan waktu yang lebih singkat. Tentunya hal tersebut telah membantu masyarakat pedesaan yang selama ini tidak memiliki Sertipikat Hak Atas Tanah dikarenakan prosesnya yang lama dan bertele-tele.

\section{Rekomendasi}

Surat Edaran Menteri Agraria dan Tata Ruang/BPN No.1756/15.I/IV/2016 dalam sistem pendaftaran tanah pertama kali kedudukannya dalam sistem pendaftaran tanah tidak kuat dikarenakan bentuk aturan perundang-undangnya yang tidak terdapat dalam tata aturan perundang-undangan Indonesia sehingga nantinya apabila membuat aturan perundang-undangan yang terkait dengan agraria disarankan dalam bentuk aturan perundang-undangan yang terdapat di dalam aturan perundang-undangan. Surat Edaran Menteri Agraria dan Tata Ruang/BPN No. 1756/15.I/IV/2016 dapat diberlakukan akan tetapi pemerintah harus mengeluarkan peraturan baru yang menambah satu alat bukti guna mengganti SKT.

\section{DAFTAR PUSTAKA \\ Peraturan Perundang-undangan:}

Undang-Undang Dasar 1945.

Burgerlijk Wetboek.

Herzine Indonesische Reglement (HIR).

Rechreglement Voor de Buitengewestern (RBg).

Undang-Undang Nomor 5 Tahun 1960 tentang Agraria.

Peraturan Pemerintah Nomor 24 Tahun 1997 tentang Pendaftaran Tanah.

Peraturan Menteri Nomor 3 Tahun 1997 tentang Ketentuan Pelaksanaan Peraturan Pemerintah Nomor 24 Tahun 1997.

\section{Buku:}

A.P. Parlindungan. (2002). Pendaftaran Tanah di Indonesia. Bandung: Mandar Maju.

Ali Achmad Chomzah. (2003). Hukum Pertanahan

Seri Hukum Pertanahan III-Penyelesaian Sengketa Hak Atas Tanah dan Seri Hukum Pertanahan IV-Pengadaan Tanah Instansi Pemerintah. Jakarta: Prestasi Pustaka.

Aminuddin Salle, et.al. (2010). Hukum Agraria. Makassar: AS Publishing.

Bagir Manan dan Kuntara Magnar. (1987). Peranan Peraturan Perundang-undangan dalam Pembinaan Hukum Nasional. Bandung: Armico. Boedi Harsono. (2008). Hukum Agraria Indonesia: Sejarah Pembentukan Undang-Undang Pokok Agraria, Isi dan Pelaksanaannya. Jakarta: Djambatan.

(2013). Hukum Agraria Indonesia. Jakarta: Penerbit Universitas Trisakti.

Jimly Asshiddiqie dan M. Ali Safa'at. (2006). Theory

Hans Kelsen Tentang Hukum. Cet. I. Jakarta:

Sekretariat Jenderal \& Kepaniteraan Makamah Konstitusi RI.

Mudjiono. (1999). Politik Agraria NasionalHubungan Manusia dengan Tanah yang Berdasarkan Pancasila. Yogyakarta: GAMA University Press.

Muhammad Yamin Lubis. (2011). Pencabutan Hak, Pembebasan dan Pengadaan Tanah. Bandung: Mandar Maju.

Samun Ismaya. (2011). Pengantar Hukum Agraria. Yogyakarta: Graha Ilmu.

Suardi. 2005. Hukum Agraria. Jakarta: Badan Penerbit IBLAM. 
Urip Santoso. (2011). Pendaftaran dan Peralihan Hak Atas Tanah. Jakarta: Kencana Prenadia Media Group.

\section{Jurnal:}

Benedicta Putri Dumatubun. (2016). "Pelaksanaan Pendaftaran Tanah Pertama Kali (Konversi Hak Milik Atas Tanah Adat) dalam Rangka Memberikan Jaminan Kepastian Hukum di Kabupaten Merauke”. Yogyakarta: Fakultas Hukum Universitas Atma Jaya Yogyakarta.

Eko Sugitario. (2007). "Hubungan Hukum dan Politik". Jurnal Yustika. Volume 4, h. 2.

Fani Martiawan Kumara Putra. (2013). "Tanggung Gugat Debitur Terhadap Hilangnya Hak Atas Tanah Dalam Obyek Jaminan Hak Tanggungan". Jurnal Yuridika. Fakultas Hukum Universitas Airlangga. Volume 28 Nomor 2 Edisi Mei.

. (2015). "Pembatalan Sertipikat Hak atas Tanah Karena Cacat Administratif Serta Implikasinya Apabila Hak Atas Tanag Sedang Dijaminkan". Jurnal Perspektif. Fakultas Hukum Universitas Wijaya Kusuma Surabaya. Vol. 20 No. 2 Edisi Mei, h. 101-117.

Hasanuddin Hasim. (2017). "Hierarki Peraturan Perundang-undangan Negara Republik Indonesia". Madani Legal Review. Vol. 1 No. 2 Desember.

Ramadhana Muhammad. (2015). "Hambatan dan Solusi dalam Pelaksanaan Proyek Operasi Nasional Agraria (Prona) Secara Gratis di Kota Malang (Studi di Kantor Pertanahan Kota Malang)". Jurnal Mahasiswa Hukum. Volume 4 Nomor 2.

Ryan Alfi Syahri. (2014). "Perlindungan Hukum Kepemilikan Hak Atas Tanah”. Jurnal Ilmu Hukum Legal Opinion, Edisi 5 Vol. 2.

\section{Skripsi/Disertasi/Paper:}

Ahmad Hasan Suyuthi. (2011). "Pelaksanaan Pendaftaran Tanah Secara Sistematik Melalui Program LMPDP (Land Management and Policy Development Project) di Kecamatan Ringinarum Kabupaten Kendal". Skripsi. Semarang: Fakultas Hukum Universitas Negeri Semarang.
Dian Retno Wulan. (2006). "Pelaksanaan Proyek Operasi Nasional (Prona) di Kabupaten Karanganyar. Disertasi. Semarang: Program Pascasarjana Universitas Diponegoro.

Fahmi CMD Widodo. (2013). "Hubungan Manusia dengan Tanah". Jakarta. Paper Administrasi dan Kebijakan Pertanahan.

Nova Susanti. (2017). "Pendaftaran Tanah Pertama Kali, Berdasarkan Jual Beli di bawah Tangan di Kabupaten Padang Pariaman”. Tesis. Padang: Fakultas Hukum Program Magister Kenotariatan Universitas Andalas.

\section{Website:}

Administrator. (2017). "Pendaftaran Tanah". https:// www.atrbpn.go.id/, diakses pada tanggal 9 Mei 2017 pada Pukul 10:00-11:00 WIB.

Bilal Dewansyah. (2014). "Kedudukan Peraturan Menteri dalam Hirarki Peraturan". https:// www.hukumonline.com/klinik/detail/ lt5264d6b08c174/kedudukan-peraturanmenteri-dalam-hierarki-peraturan-perundangundangan, diakses pada tanggal 13 Mei 2017 pada Pukul 09:00-10:00 WIB.

Indra Gumilar. "Sistem Torrens". https://www. slideshare.net/mobile/igum26/sistem-torrens/, diakses tanggal 13 Mei 2017 pada Pukul 09:0010:00 WIB.

Irma Devita. "Untuk Persertifikatan Tanah Tidak Perlu lagi Surat Keterangan Tanah dari Kelurahan". http://irmadevita.com/2016/untukpensertifikatan-tanah-sudah-tidak-perlu-lagiskt-dari-kelurahan/, diakses pada tanggal $12 \mathrm{Mei}$ 2017 Pada pukul 09:00-10:00 WIB.

Jesica Lestari, dkk. "Perbedaan Surat Edaran, Peraturan Menteri dan Undang-Undang". http://jesicalestari29.blogspot.co.id/2017/06/ perbedaan-surat-edaran-peraturan-mentri.html, diakses pada tanggal 13 Mei 2017 Pada pukul 09:00-10:00 WIB.

Solichin Ristiarto. "Pengaturan Tanah Ulayat di Indonesia dan Australia". http://www.academia. $e d u$, diakses pada tanggal 15 Agustus 2017.

Wibowo Tunardy. "Macam-Macam Hak Penguasaan Atas Tanah". http://www.jurnalhukum.com diakses pada tanggal 10 September 2017. 